\title{
GEOMEDIA`S ROLE IN THE GEOSYSTEM DEVELOPMENT: DRACULA`S SPATIAL IMAGINARIES IN ROMANIA
}

\author{
Mihai VODA ${ }^{1}$, Steven GRAVES ${ }^{2}$, Cristina Elena BERARIU ${ }^{3}$
}

DOI: $10.21163 / G T \_2019.142 .13$

\begin{abstract}
:
Geomedia techniques are easily acquired, freely available and easy to learn. Most of the modern mobile phones possess digital camera and have incorporated Global Positioning System. Various smartphone applications can be downloaded and used to find, create and control the virtual representations of places, emphasizing humans' central position in the Geosystem. The focus of this research is an assessment of the power of Geomedia techniques as a tool in the identification, construction and development of functional Geosystems. Methodologically, our research in Romania used the grounded theory with data collection based on smartphone apps, web GIS and geospatial datasets from Google Earth, combined with the Geomedia analytic hierarchy (GAH) and the multicriteria decision making (MDM) processor for the geosystems`effectiveness evaluation. We demonstrate how the growing popularity of Geomedia tools can be used to efficiently sustain development in an organized way, at both the national and community levels.
\end{abstract}

Key-words: Romania, Geomedia, Dracula, Geosystem, Smartphone apps, Development.

\section{INTRODUCTION}

Geomedia`s imagined place experience illustrates the human`s created virtual Geosystems with the complexity of functional interrelated components. Geomedia synthetize all the information that connects different places illustration with coordinates and Geosystem`s characteristic data. All environmental elements are contributing to a geographical place's unique personality, which is spatially developed as a Geosystem, defined by common and unique attributes (Voda \& Montes, 2018).

The Geomedia techniques are used by everyone that takes photos with the smartphone`s GPS activated and shares the images on social media, Google Maps, Pinterest, Google Earth or Aibnb. Cherifi et al. (2014) argued that conventional crowd shared images are used for the creation of a destination virtual imagery and Relph (1976) claimed that its qualities influence people`s imagined experience of that place. Croitoru et al. (2013) explained the importance of collective geolocated media generated through web services due to smartphones advancements.

From a Geomedia perspective, the geographical place, once properly surveyed (scanned, measured, photographed) and transformed in a virtual reality model, can become a scientific illustration of an entire Geosystem characterized by 'interconnected physical and social relations'(Lapenta, 2011, p.16), with active energy, information and matter fluxes between humans and their living environments.

${ }^{1}$ Dimitrie Cantemir University, 540546 Targu Mures, Romania, mihaivoda@cantemir.ro;

${ }^{2}$ California State University, Northridge, CA 91330-8249, U.S.A., steve.graves@csun.edu;

${ }^{3}$ Dimitrie Cantemir University, 540546 Targu Mures, Romania, cristina.berariu@cantemir.ro. 
This article analyzes the effectiveness of Geomedia techniques in the Geosystems sustainable development processes by exploring how communities contribute to the identification and promotion of places unique attributes through an analysis of Dracula phenomenon in Romania. This innovative approach focuses on geo-locational issues in a variety of Vlad T,epeș related places; their contradictions, and the role of Geomedia in the evolving Dracula-based Geosystems.

At first glance Geomedia and Geosystems may seem unrelated, albeit both of major concern. However, accumulated knowledge on virtual reality representation of places indicates that Geomedia techniques are more efficient in specific Geosystems, leading to our research question: how do Geomedia stimulate Geosystems development? This question is highly important for finding the best way to manage the Geosystem`s virtual inception, presentation and contextual perception in different cultures.

The Geosystem is like a living organism which thrives under dynamic equilibrium conditions, generating welfare for its inhabitants if they are capable to control the matter, energy and information fluxes. It's extension varies in accordance to the human collectivity egregore that defines the geographical space and stimulates components interaction with the new technologies help: Geomedia (Voda et al., 2019). This research shows that Geomedia is much more than just a reliable source of information. Geomedia is also a unique type of crowd-sourced knowledge created by individuals using a variety of applications that convey their collective values and beliefs.

Modern researchers argue that a message stems from the social context in which it was produced, equally influencing and being influenced by it (Fairclough, 1995; Johnstone, 2002). As in any type of discourse, Geomedia is invested with powers that go beyond the apparently simple message it provides by means of maps, photos and texts, it conveys the cultural identity of the people living in the Geosystem. Any place with a story to tell, with feelings to generate or thoughts to trigger, can, leverage Geomedia to stimulate the valuable sense of place among locals. Once well done Geomedia becomes widely shared, it has the power to bond the community members, connecting them to the local egregore and creating a self-sustaining Geosystem. The activated flows of matter, energy and information will increase the local Geosystems` functionality, initiating its development.

The new high-tech solutions and software apps availability that Lapenta (2011) refers to as Geomedia, are represented today as internet platforms where location-based and augmented reality technologies merge in a new form of digital visualization system activated and maintained by social media data exchange power. The humans are the principal piece of their Geosystem, whose empirical scientific illustration evolved from paper maps to virtual computer and smartphone geo-apps (Voda, 2013; Zheng et al., 2010).

This article contributes to the understanding why Geomedia controls Geosystems by synchronizing social etiquette, reshaping spatial imaginaries and harmonizing media interactions. As Lapenta (2011, p.15) observed 'Geomedia are to space what the watch is to time. The future of location aware geospatial technologies is created with web-based Geographical Information Science (GIS), smart apps and interactive digital mapping (Wilson, 2012; 2014). Inal et al. (2017) pointed to the value of location-aware smartphones for archaeological field work. Baiocchi et al. (2017), showed the importance of the new Global Navigation Satellite Systems (GNSS) techniques introduced for smartphones in the virtual maps creation process.

Various researchers have examined this issue, notably Wilson (2014, p.298), who outlined the variety of geospatial data interfaces, pointing to Google's "check in" function (also found in Facebook, and other social media) and how the geo-aware social media have 
become important to the comprehension of local cultures. Dickinson et al. (2014), Sidali et al. (2017), Meng et al. (2014), demonstrate how Geomedia, through a diversity of smart applications provide directions and information, adding value to the historical and geographical resources of a place. Geomedia techniques offer various visualization opportunities for the chosen Geosystem, considerably influencing development decisions (Voda \& Negru, 2015). Echtner and Ritchie (2003), noted that unique functional attributes were of great importance for a geographical location's image.

Recent research suggests that Geomedia users are producing and sharing photos, symbols and text in a way that has significantly reconfigured the interaction of social media and the slightly older world of digital mapping (Lapenta, 2011, p 17; Zheng et al., 2010).

The considerable achievement of the Airbnb's locations for example, is largely a product of new business models afforded by a better visualized Geosystem (Voda \& Montes, 2018). Once validated by excellent ratings, the Geosystem's virtual image might attract more visitors, transforming the locals into superhosts, thereby increasing their revenue (Wang \& Nicolau, 2017; Liang et al., 2017; Gunter, 2018). Furthermore, the Airbnb phenomenon proved the functionality of local Geosystems virtual imagery, sustained and validated, if genuine, by visitors` reviews (Guttentag \& Smith, 2017; Cheng \& Jin, 2019).

Airbnb experience of a place will definitely contribute to the local Geosystems presentation and outer contextual perception because today, Airbnb represents the world leader in peer-to-peer accommodation provision (Sigala, 2017). Anyone can become a host using identification documents and a property's photos as a part of their envisioned Geosystem image. Guttentag (2015) explained the considerable influence of the Airbnb system through the disruptive innovation theory, while Ert et al. (2016) emphasized the critical value of personal images to the platform's construction of credibility among wouldbe customers. Tussyadiah \& Pesonen (2016) observed that the host's incorporation in local community encourages social relationships, enhancing the Airbnb system's efficiency and reliability. From this research Geosystems perspective, the community is comparable to organic entities, with functional common and unique attributes operating in dynamic balance to satisfy its social needs. This article will explore how the use of Geomedia techniques contributes to the place-making efforts of any Geosystem, possibly creating real value as it develops. Geomedia can also become the ultimate type of advertising, with world-wide impact, without the costs typically incurred via expensive, professional and/or governmental marketing efforts (Gupta et al., 2018; Voda \& Montes, 2018).

As technological innovation increasingly becomes critical to sustainable development in many locations around the globe, it is worthwhile to examine its impact in Romania, a country easily accessed by both European and North American visitors, with excellent digital infrastructure, and a large number of locals using smartphone applications (Statista, 2018), but with a relatively poorly organized government-based infrastructure.

Romania is today somewhat reliant on the mythology of Dracula, which attracts considerably more visitors to the region than any other touristic attraction. Centered on the Transylvania region of Romania, the Dracula phenomenon is unique and with the support of Geomedia tools could become even more important to Romania's overall development goals (Voda \& Negru, 2015; Ernawati et al., 2018).

Specific myths and legends can create powerful brands for the sustainable tourism development (Robinson \& Wiltshier, 2011; Ernawati, 2015). As such, Dracula related Geosystems generate broader understanding of the Geomedia techniques role in the construction, content and outer perception of our social worlds. 


\section{RESEARCH METHODOLOGY}

The research methodology is based on the grounded theory using Geomedia techniques for models creation and data analysis. Using the Geomedia techniques in every location, a group of seven criterions were identified as representative for the proper assessment of the Geosystem`s effectiveness: unique attributes, innovation diffusion, geo-referenced illustrations, geomedia competence and the access to geomedia (Voda et al., 2019).

Data collection procedures were based on the specific geographical information systems visual imagery connected to the Dracula phenomenon. The datasets analysis and attributes particular assessment was done using INIS Viewer, Google Maps and Google Earth internet platforms. Comparative analysis revealed Geosystem`s components properties, significantly contributing to the unique attributes identification (Croitoru et al., 2013; Lapenta, 2011; Ernawati et al., 2018; Voda et al., 2017; Zheng et al., 2010). Based on the Romanian Dracula phenomena, this research attempts to emphasize the importance of the local Geosystems` unique attributes and predict future wider applicability of the Geomedia techniques.

Selective coding was applied for Geosystems`access to Geomedia (60-0.150), Geomedia competence (70-0.175), unique attributes score (100-0.250), innovation diffusion (90-0.225) and geo-referenced illustrations (80-0.200) in order to understand the context of Geosystem`s imagery creation, reception and display. Each criterion weight was attained by the geomedia analytic hierarchy (GAH) (Voda et al., 2019). Geomedia technique is integrating all the environmental features in virtual Geosystems with functional interrelated components and fluxes of matter, energy and information. The process returned the selected Geosystems in an array, implying their synthesis and processing into new structures, according to people`s energy inputs and personal experience of the geographical place (Park \& Santos, 2017; Voda et al., 2019). It also requires various fluxes identification, attributes interpretation and structure-components property correlations. Finally, the specific behavioral computation was possible and each Geosystem`s effectiveness obtained (Mac, 1996). Our goal was to elaborate Geomedia techniques capable to extend functional Geosystem`s performance and extrapolate its virtual representations qualities.

The unique attributes criterion was considered the most important, receiving the maximum relative weight (rw) of 100-0.250. It reflects the geosystem`s authenticity generated by special geographical features, intriguing historical facts, myths or legends. The next value of $90 \mathrm{rw}$ was given to the innovation diffusion criterion because it shows the geosystem`s inclusion probability in transformative networks. The georeferenced illustration $(80 \mathrm{rw})$ criterion reflects the geosystem`s virtual presence online. Geomedia competence (70 rw) and geomedia acces $(60 \mathrm{rw})$ are conected to the people`s ability to use geomedia tools and their acces to online internet information (Voda et al., 2019).

The Geomedia data collection techniques involved geographic information, historical texts and documents analysis combined with field work in the selected Dracula related Geosystems. Data was collected during 2015-2018 research field trips in Bran, Sighişoara, God`s Chair, Devil`s Plateau and Borgo Pass geographical areas where 67 locals were asked to rate (<2-very weak, 3-4 weak, 5-6 moderate, 7-8 strong, 9-10 very strong) their access to Geomedia and Geomedia competence. Zheng et al. (2010) believed that georeferenced images incorporate substantial data related to their geographical area culture. 691 relevant geo-tagged Facebook posts and Google geo-referenced illustrations were selectively coded.

We observed the inner context of created imagery and assessed the outer perception of their visual presentation. Yanai et al. (2009) claimed that specific geographical locations 
cultural differentiation can be identified by the extraction process of the most relevant visual images and the emblematic conceptualization confirmed throughout an assembling procedure. Coding the outer context of visual data was essential to understand the act of inception, the act of representing different Geosystems, their content, their contextual perception and development role in the Romanian context (Table 1).

Table 1.

The relative weight for each criterion used for Dracula related Geosystems.

\begin{tabular}{|c|c|c|c|c|c|}
\hline $\begin{array}{c}\text { Geosystem`s } \\
\text { name }\end{array}$ & $\begin{array}{c}\text { Access to } \\
\text { Geomedia }\end{array}$ & $\begin{array}{c}\text { Geomedia } \\
\text { competence }\end{array}$ & $\begin{array}{c}\text { Unique } \\
\text { attributes } \\
\text { score }\end{array}$ & $\begin{array}{c}\text { Innovation } \\
\text { diffusion }\end{array}$ & $\begin{array}{c}\text { Geo-referenced } \\
\text { illustrations }\end{array}$ \\
\hline Bran Castle & 0.196 & 0.174 & 0.217 & 0.196 & 0.217 \\
\hline Sighisoara & 0.195 & 0.171 & 0.22 & 0.22 & 0.195 \\
\hline Borgo Pass & 0.226 & 0.129 & 0.226 & 0.194 & 0.226 \\
\hline God`s Chair & 0.24 & 0.12 & 0.24 & 0.16 & 0.24 \\
\hline $\begin{array}{c}\text { Devil`s } \\
\text { Plateau }\end{array}$ & 0.211 & 0.105 & 0.263 & 0.158 & 0.263 \\
\hline
\end{tabular}

Smartphone GPS high-tech geo-location capabilities were used for photos geotagging process in the studied geographical areas and invert geo-coding were realized for the semantic connotation of specific locations associated to the given GPS coordinates. Furthermore, according to Liu et al. (2006) methodology, geographical observations have been conducted on every site in order to visualize the semantic position typology of the virtual map.

Exchangeable image file (EXIF) data viewer methodology was used for a significant variety of smartphone photos coordinates identification which were obtained from the interchange information digital files and were geo-located on Google Maps ${ }^{\mathrm{TM}}$ (Inal et al., 2017; Ernawati et al., 2018; Torpan \& Voda, 2019).

For every Dracula related Geosystem, the Facebook geottaged posts were analyzed to generate the innovation diffusion criterion. Data collected on field with the Garmin GPS and smartphone applications (Google Photos, GTCamera) was used for the geo-referenced illustrations validation. A number of 266 Facebook geo-tagged posts and 425 Google georeferenced illustrations were analyzed and the interchange information digital data extracted for the virtual Geosystems evaluation (Table 2).

The geomedia analytic hierarchy $(\mathrm{GAH})$ generated each criterion weight (Geomedia acces -0.150 , Geomedia competence - 0.175, Unique Attributes - 0.250, Innovation diffusion -0.225 , Georeferenced illustration - 0.200). The Geosystem`s effectiveness priority score was obtained using the multicriteria decision making (MDM) processor. Geosystems` geographical features, the local history and traditions are stimulating authenticity and the unique attributes creation ( $\mathrm{Xi}$ et al, 2015). The innovation diffusion is important for the integration capacity in transformative networks. The effectiveness weighted sum is reflecting every analyzed Geosystem`s functionality and it is positively correlated with the Arrow`s theorem results which validated the application of Geomedia techniques and the GAH process (Arrow, 2011; Voda et al., 2019). 
Table 2.

Dracula related Geosystems`effectiveness evaluation.

\begin{tabular}{|c|c|c|c|c|}
\hline Geosystem`s name & $\begin{array}{c}\text { Interviewed } \\
\text { people }\end{array}$ & Arrow points & Arrow score & $\begin{array}{c}\text { Geosystem`s } \\
\text { effectivness }\end{array}$ \\
\hline Bran Castle & 16 & 5 & 9 & 92.75 \\
\hline Sighisoara & 19 & 4 & 8 & 83 \\
\hline Borgo Pass & 11 & 2 & 6 & 62.5 \\
\hline God`s Chair & 12 & 1 & 5 & 50.25 \\
\hline Devil`s Plateau & 9 & 0 & 4 & 38.75 \\
\hline
\end{tabular}

\section{SIGHIŞOARA AND BRAN GEOSYSTEMS`EFFECTIVENESS.}

The two most popular Dracula-themed locations in Romania are Bran Castle and the citadel of Sighișoara. Each of these locations has a balanced and robust virtual Geosystem that contributes to the maintenance of a sustainable local tourism industry.

Both locations have similar Geosystems. Climate characteristics are similar, recommending both Sighişoara and Bran for sightseeing all year round. We analyzed the inner and outer context of the natural landscape features that include mountainous terrain, slightly forested hills and poor road networks, coded as functional attributes of both locations $(0.220 / 9-0.217 / 10)$.

The acts of representing Geosystems`visual images was linked to the context of their creation, generating historical credibility to both places because of their connection to the real character, Vlad Țepeș the Romanian ruler. Their unique attributes score and innovation diffusion values are very strong (0.196/9-Bran). The Sighişoara and Bran Geomedia virtual imagery is combining 'geo-location, social data and the wisdom of the crowd for the credible linkage of geographical reality to the virtual imagery creation (Valentino-DeVries, 2010). By using slices of the visual dimension of Sighişoara and Bran representations (101 geo-tagged posts, 166 geo-referenced illustrations), the first Dracula Geosystem models computation and structure-elements attributes correlations was possible. The analysis finds the highest priority score in Bran (92.75/9) reflecting its Geosystem`s effectiveness, closely followed by Sighișoara (83/8).

Sighișoara's old citadel was one of seven walled fortresses built by Transylvania Saxons, but since it is also where Vlad Țepeș was born, it has become an important destination for Dracula tourism. The description of the multilayered context of visualization was performed here in order to understand the Dracula phenomenon connection processes to the Geosystem's functionality. There is a slighter higher value for the access to Geomedia in Bran (0.196/9) compared to Sighișoara (0.195/8).

On the main square of the citadel sits the yellow house of his father, Vlad Dracul. Plotting situational maps of visual data, all the analytically pertinent elements were analyzed, including the house that represents the core of the local Geosystem: the locals' Geomedia competence has a strong score of $0.171 / 7$. It has been transformed into a significant tourist attraction featuring a traditional restaurant on one floor, and the "Dracula Rooms" on the second floor where crowds of tourists gather before or after eating the "must have" lunch, recommended by digital travel guides authored by fellow tourists. 
Dracul name (meaning Devil in Romanian), derives from the Order of Dragon, a semimilitary organization Vlad Dracul was a member of. The Dracula Resurrection movie validates Sighișoara's fortress symbolic elements of Dracula`s particular image by choosing it for filming locations. Furthermore, the Romanian Ministry of Tourism started the Dracula Park project initiative, envisioned to develop tourism in the region by taking advantage of Dracula as a lucrative myth (Jamal \& Tanase, 2005; Voda \& Negru, 2017).

Echtner and Ritchie (2003), emphasized the unique functional attributes importance for a destination`s image (0.217/10-Bran). Lai and Li (2016), argued that tourist`s destination image reveals the mental perceptions held by visitors about a place $(0.196 / 9$ Bran, 0.220/9- Sighişoara). Sighişoara (0.195/8) and Bran (0.217/10) geo-referenced illustrations score demonstrate their central and effective Geosystems, which is in line with Asero et al. (2016) explained how tourist may perceive a tourism area as central or peripheral within a network. The local communities are actively contributing to the valorization of their place unique attribute, Dracula (Fig. 1).
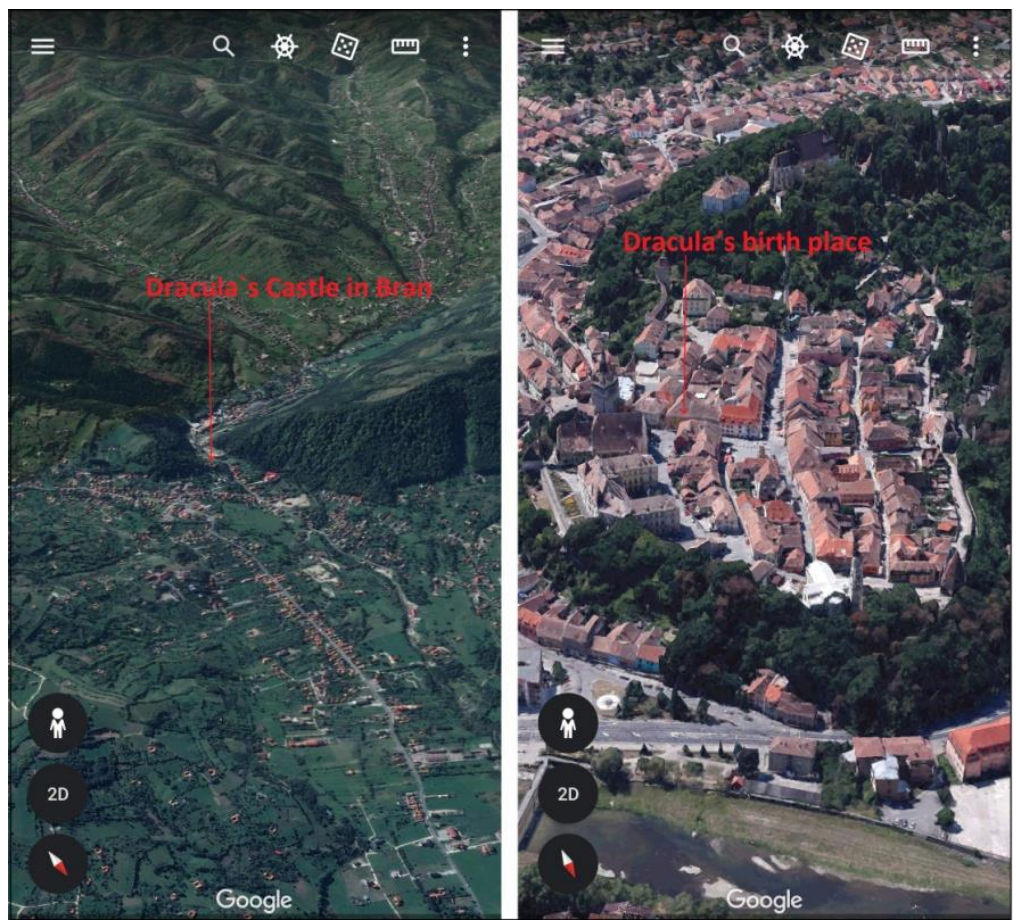

Fig. 1. Bran Castle near Brasov and Vlad Dracul house in Sighişoara (Google Earth, 2017).

The village of Bran has a less historically viable connection to Vlad Țepeș, but thanks to robust Geomedia efforts and perhaps its proximity to Bucharest, is the best developed of the Dracula Geosystems in Romania (92.75/9).

Multiple historians including Anghel (2006) and Curta (2014), agree there is evidence that Vlad Țepeș never actually inhabited Bran Castle. The castle itself was constructed by the inhabitants of Brasov, a city nearly $30 \mathrm{~km}$ away as a distant bulwark against invasion 
from the South. Perhaps Vlad III bypassed Bran castle during an invasion in the mid-1400s, but never lived there.

The association between the Castle and Vlad Țepeş was invented by Romanian authorities after an International Tourism Trade in 1991. According to Roberts and Simpson (1999), tourism development around Bran was initiated with the help of the international operation Villages Roumains, a non-governmental organization under the European Union PHARE funding scheme.

Bran's location is convenient due to its proximity to Brasov, less than three hours from Bucharest (Anghel, 2006; Baca \& Rusu, 2017). Bran Dracula Geosystem`s high innovation diffusion (0.196/9) and geo-referenced illustration score $(0.217 / 10)$ confirm the widely held expectations of an imagined place experience. It is located on a spectacular high cliff in Bran village, close to a defensible chokepoint pass (Fig. 1).

The architecture and its situation on a cliff, against a rugged backdrop of the Carpathians allow tourists to meet their expectations for a "Scary Castle", worthy of Dracula - the Prince of Darkness to be met in spades (Muresan \& Smith, 1998; Voda \& Negru, 2017).

For geospatial smart applications development, the Geomedia travel pattern analytic approach can display people's visiting preferences and thus facilitate traffic patterns observation. Geomedia is linking geography, spatial and visual reality perception offering information, visual examples and apprehension of a specific geographical location (Zheng et al., 2010).

Vlad III was constantly trying to foster and protect his state, being considered cruel, but not mentally ill (Giurescu \& Giurescu, 1975). Wallachia`s Prince ferocity was dramatized by his Saxon enemies from Southern Transylvania. Vlad III was known as Tepeş (the impaler) only in the 'fifteenth to sixteenth century' (Stoicescu, 1976). The collective stereotypical images created about Transylvania are related to Dracula myth. Cherifi et al. (2014) emphasized the importance of people's naïve images, the virtual representation of a destination, generated by the non-visitors.

Vlad III had two nicknames: Țepeș (The Impaler) and Dracula. Dracula meant the son of Dracul, his father's name after receiving the Order of the Dragon in 1431, from King Sigismund of Hungary (Curta, 2014; Butulescu, 2001). According to Butulescu (2001), Vlad III used to sign as Dracula. Butulescu`s arguments are based on the historical document signed on the $20^{\text {th }}$ of September 1459 by Vlad III his portrait made by Odhsenbach Stambuch from Stuttgart (Butulescu, 2001).

Both Vlad Dracula related Geosystems are properly balanced in a dynamic equilibrium. Energy inputs from locals and tourists drive the Bran and Sighișoara Geosystems. They interact with the human activities around the Castle in Bran village and inside the Old Citadel in Sighișoara. The evidence for this interaction is the tourism development processes that gave rise to the Geosystems main outputs: genuine and functional tourist sites (USGS, 2017; Ernawati et al., 2018). The fictionalized landscapes are given credibility and legitimacy by the frequent retelling of the myth through the Geomedia rich reproduction of the narrative by tourists.

The effectiveness of Geomedia techniques is also reflected in the evolution of peer to peer property rental industry in Bran (0.196/9-AG, 0.174/8-GC) and Sighișoara (0.195/8AG, 0.171/7-GC), in accordance to Ernawati et al., (2018) who showed the importance of the geo-referenced media for the local community-based tourism development which can use the Airbnb website platform, Facebook geo-tagged posts or Google Earth pinned locations to better valorize their resources. Many inhabitants rent their homes in Airbnb 
online accommodation system. In the Bran castle area, for example, there are 43 private houses registered. The number increases to 59 in Sighişoara, where the old citadel has been constantly visited since 2010, when the nearby Biertan village appeared on the Lonely Planet's Romania tourist guide (Voda, 2013; Airbnb, 2018).

\section{BORGO PASS, GOD`S CHAIR AND DEVIL'S PLATEAU GEOSYSTEMS}

Borgo Pass and God`s Chair are two relatively inaccessible Dracula Geosystems descriebed in Bram Stoker`s book. Like Bran Castle, they also have a tenuous connection to Vlad Tepes, but both locations appeal to true fans of the Bram Stoker's novel. Borgo Pass and God`s Chair are fictional counter parts of Pasul Tihuța and Scaunul Domnului. These locations appeal more to les connoisseurs of mythology and leged, those sometimes known as the "Dracula Hunters", than they do to conventional visitors.

Petru and Nastase (2004), suggest that after reading Bram Stoker's Dracula, Alexandru Misiuga, the director of the Bistrita County Tourism Authority, claimed that Stoker's "Borgo Pass", exists in the real world in the Northern part of the Calimani Mountains (as Pasul Tihuta). Based on this claim the local authorities decided to build a hotel that they would call "Dracula Castle" in order to boost the regional tourism development. Misiuga managed to obtain the necessary funds (25 million lei) from the central communist authorities in Bucharest. The castle was built at 1227 meters altitude between 1976-1983 (Petru \& Nastase, 2004; Mânzat, 2008; Baca \& Rusu, 2017).

The Dracula Castle Hotel slightly resembles a medieval castle. The architectural style also clearly suggests Socialist Classicism, common among apartment blocks erected for the working class during the communist era. Dracula Castle's was initially supposed to be built on the way from Piatra Fantanele to Ciosa, on the Paltinului ridge, near Frumuseaua Peak (Mânzat, 2008). That location would have been more credible and successful in terms of a Geomedia imagery development because it has an interesting history, though on a lesstravelled road.

Borgo Pass Dracula Geosystem's attractiveness (0.226/7-UAS) can be improved through Dracula themed activities. In line with Barbieri et al. (2016) who suggests that local community involvement represents a prerequisite for the tourist experience success, our results show relatively good Geomedia access $(0.226 / 7-\mathrm{AG})$ but low competence level (0.129/4-GC).

Attractions that leverage the Dracula theme could include, black horse-drawn carriage rides on dirt roads, vampire-themed paragliding adventures and attractions like jacuzzi tubs fashioned as witches cauldrons. Managed well, it could increase the innovation diffusion (0.194/6-ID) score.

We analysed the Borgo Pass Geosystem's specific functional features, assessing how the Dracula imagery structure correlated to the tourists' experience of the place. The lower 0.226/7-GI score show that energy inputs from visitors slightly drive the unbalanced Dracula Geosystem. As a result, there are no few viable outputs such as, tourist site creation and tourism activities development.

The Geomedia imagery could help generate processes that contribute to the fabrication of a more effective Geosystem (62,5-GE, 6-AS), like we observed in other Vlad Dracula related sites in Bran(92,75-GE, 9-AS) and Sighișoara(83-GE, 8-AS). Their virtual representations qualities can be extrapolated to the Borgo Pass Geosystem and interconnected to God`s Chair's functional attributes. 


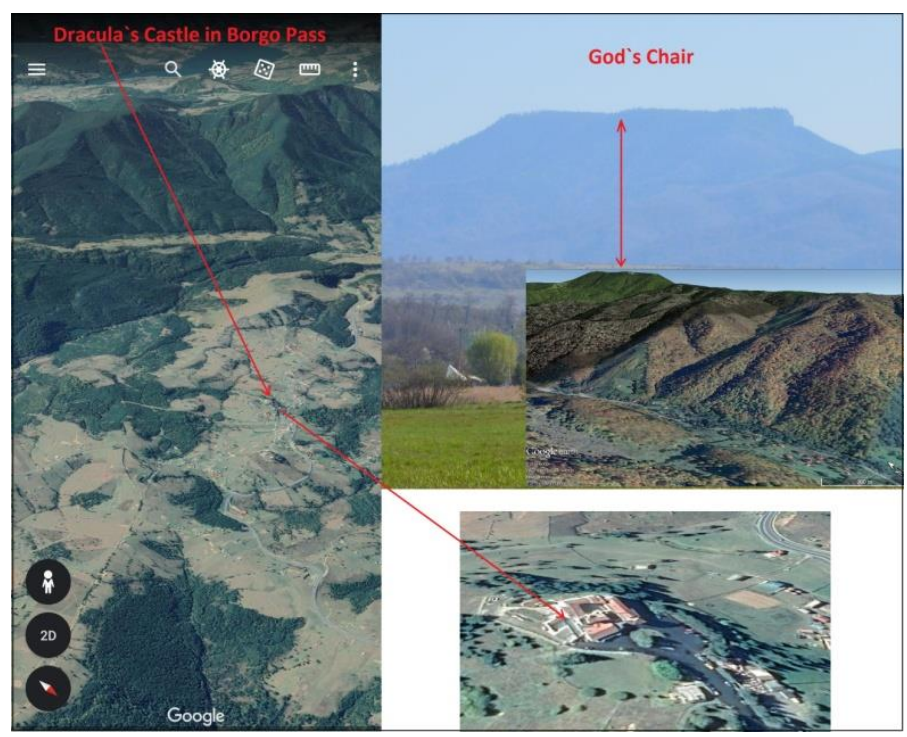

Fig. 2. Dracula Castle from Borgo Pass and God`s Chair (Google Earth, 2017).

The results suggests that the following Borgo Pass (Fig. 2) myths can strongly increase its unique attributes score (0.226/7-UAS) and overall Geosystem`s effectiveness (62,5-GE, 6-AS): one is locating an old Vlad citadel on the Frumuseaua Peak; another states that the Golden Hen treasure is buried there on the mountain ridge; there is also a legend about Barbu Blacul, Vlad Țepeș`s lieutenant who came on Frumuseaua Mountain in search for the citadel and the hidden treasure; the myth of Ianca and the ghost army is correlated with loud voices, laughs and strange globular lights on Frumuseaua Peak during night times. The cave legend refers to a time travel compression: you enter young and come out old; you die if you tell anyone. There is also a legend about ancient times when the locals suffered of a blood disease, being annoyed by the sunlight, with whitening skin, growing teeth and lips; the remedy was animal blood consumption. The haunted house legend is considered a real story about a group of youngsters who spent a night in a hut situated in the Frumuseaua Peak proximity (Baca \& Rusu, 2017).

God's Chair (Scaunul Domnului/ Isten Szeke) is a flat, but sheer-sided mountain top located (1381 meters) in the volcanic Calimani Mountains Range (Fig. 2), about $24 \mathrm{~km}$ south of the Borgo Pass. The interesting Dracula related Geosystem (0.240/6-UA) is visible from the Reghin-Bistra Muresului road, following the Mures River Valley upstream. Stoker (1897, pp.8) described it in the original Dracula book: 'Look! Isten Szek!'- 'God`s seat!', as Jonathan Harker travelled Transylvania in search for Dracula's Castle, just before entering the mountains to the Borgo Pass (Voda, 2013; Voda \& Negru 2017; Baca \& Rusu, 2017). Although the Geomedia competence score is very low $(0.120 / 3-\mathrm{GC})$, our results show similar values $(0.240 / 6)$ for the geo-referenced illustrations and unique attributes suggesting that the Dracula themed projects initiated in Bistra Muresului village towards the mountainous gravel roads connecting to Borgo Pass will increase Geosystem`s effectiveness in the future (Voda \& Negru 2017; Ernawati et al., 2018). This is in line with Hwang and Stewart (2017) who found that collective actions of the local communities are very important for a sustainable community-based tourist infrastructure development. 
Iszten Szeke and Borgo Pass in Romania could very well benefit from capitalizing on the local Dracula's myth to attract more tourists (House, 1997). Other European locations such as La Mancha in Spain, Copenhagen in Denmark or Lapland from Finland successfully valorized Don Quihote, Little Mermaid and Father Christmas themes in tourism development (Muresan \& Smith, 1998). Dracula character has fictional mixed origins given by the real historical events and people connections, capable to strengthen the local Geosystem`s unique attributes and increase its effectiveness (50.25-GE, 5-AS). In Bram Stoker`s book, the Romanians are the proud descendants of the Dacians and Dracula is a local born Prince with Szekely blood (Stoker, 1897; Voda, 2013; Baca \& Rusu, 2017, Muresan \& Smith, 1998). The innovation diffusion lower level (0.160/4-ID) confirms Muresan and Smith (1998) observations that in Romania, Dracula related geographical places should generate 'a mix of fiction and realities', encouraged by literary, film and lately Geomedia references.

Apart from Borgo Pass, Frumuseaua Peak and Iszten Szeke, there is Scholomance (Solomonărie in Romanian), the mysterious underground school where Dracul (Devil) was a teacher. The black magic school from Bram Stoker`s book was geo-located in Cindrel Mountains, below the Cindrel Peak $(2224 \mathrm{~m})$ on the Iezerul Mare lake shores (Stoker, 1897; Baca and Rusu, 2017). Currently, the Cindrel's geographical area appears to be deserted, presenting no interest until 2011, when the Transylvania Calling spiritual festival was organized, proving the Geomedia techniques potential (Fig. 3). The special trance gathering created there the Wonderland magic realm. Remotely located in the mountains heights, the Geosystem is famous among the shepherds as the Devil`s Plateau.

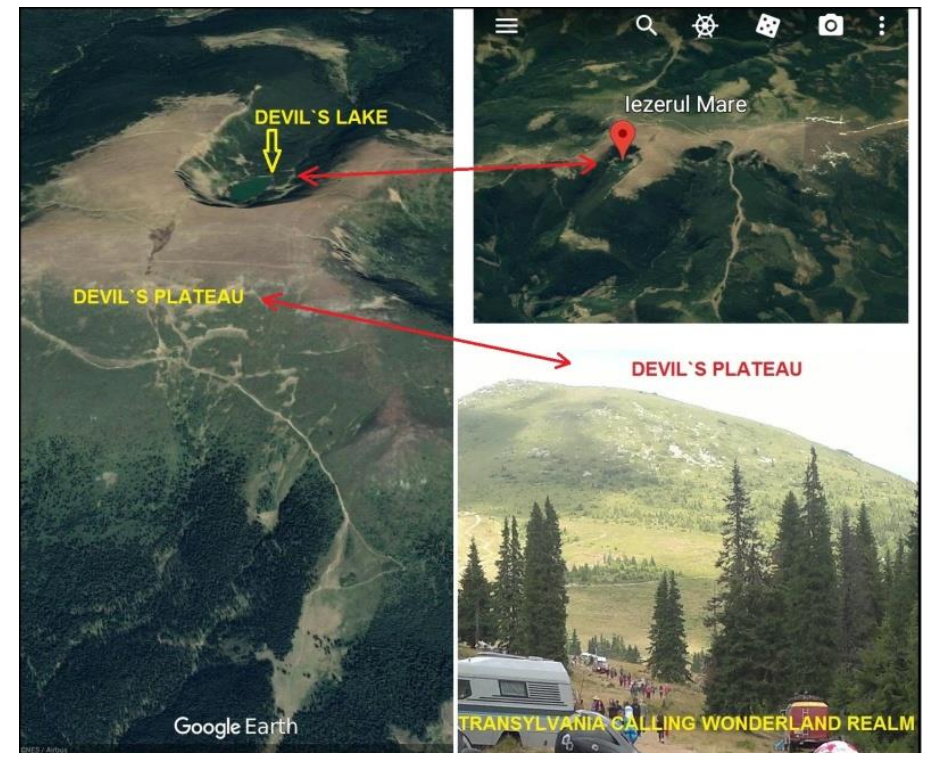

Fig. 3. Wonderland and Devil`s Plateau in Cindrel Mountains (Google Earth, 2017).

The Devil's Plateau Geosystem has the lowest competence (0.115/2-GC) and access to Geomedia (0.211/4-AG) values due to its remote geographical position. But as Ernawati et al. (2018) observed, the local inhabitants are committed to learn how to valorize the new 
technological advancements, the use of freely available Geomedia techniques for their own benefits. Suggestive photographs, reliable references, mobile phones and internet coverage, can metamorphose their remote households in exquisite rental homes, increasing their Geosystem`s effectiveness (38.75-GE, 4-AS). In accordance with House (1997) statement on legends importance, the unique attributes score $(0.263 / 5-\mathrm{UA})$ can be improved on grounds of the local legends who describe the fabled Solomonărie school location under the Devil`s lake, where selected kids learned the magic plants and hail producing secrets. The sheep man says: 'If you throw a stone into the lake` (Iezerul Mare/Devil’s lake) the angry dragon will fly out and severe weather phenomena occurs (Gerard, 1885; Oișteanu, 2004).

As Negru et al. (2015), hypothesized, Dracula`s horses-drawn carriage might have crossed the Calimani Mountains following Bistra river Cofu tributary from God`s Chair to Borgo Pass to reach the controversial castle. Ernawati et al. (2018) elaborated mountain routes GIS profile graphs for dirty tracks connection over the Calimani Range, validating the two Geosystems connection.

For the proper characterization of the Bram Stoker`s Dracula Geosystems, our study utilized a systems-theoretic formulation. Common and unique functional attributes were identified and characterized in order to generate the Geosystem effectiveness for each geographical location. Their structure-elements property correlations were evaluated using data from Vlad Dracula functional Geosystems. The specific behavioral computation revealed a considerable development potential that can be valorized in the future in a community collaborative approach linking Bram Stoker`s Dracula spatial imaginaries to the local myths and legends. Our results confirm Rinne`s (2018) statement that the sharing economy will considerably improve people livelihoods. Borgo Pass, God`s Chair and Devil`s Plateau, unlike any other remotely located Romanian site, possess the most valuable asset: Dracula, their special unique attribute.

\section{RESULTS DISCUSSION}

Bram Stoker's fictional character of Dracula launched an impressive array of vampire related media production. Dozens of movies, television shows, cartoons and theatrical productions have spun off the original volume (Miller, 2003). Luckily for Romania, the original text placed the fictional character in the real landscape of Transylvania and the association has remained firm in the imagination of many westerners for over 100 years. The analysis finds that Geomedia visualization techniques enhance locations' broader cultural and historical values, conditioning visitors' comprehension of the Dracula phenomenon. Apart from the specifically connected with Vlad Țepeș or Dracula sites, tourists are enjoying other Romania mythical places as well.

Dracula phenomenon compresses elements from literary, movie, dark, cultural and heritage tourism (Hovi, 2014). The media tourism term has been proposed to integrate literary and movie-induced tourism with the modern Internet, in an effort to quantify the popular culture Dracula tourism (Reijnders, 2011; Light, 2012; Larson et al., 2013; Hovi, 2014).

The results show that Geomedia imagery tends to increase tourist sites visitation rates by offering visitors more options via images encapsulated on smartphones, tablets and laptops. Hence Dracula related spots can be transformed into more successful tourist sites by these newly available technologies. The Geosystem theory has the capacity to explain and predict the Dracula phenomenon in connection to the Geomedia technology used to create it. Friendly interfaces facilitate the use of smartphone applications, helping the locals 
in Bran and Sighisoara to produce new visual concepts (Android Development, 2016). The study finds evidence that the future development of Dracula Geosystems becomes possible with the easily apprehended tools and Geomedia access in Borgo Pass and God`s Chair. Wang and Nicolau (2016) observed that smartphone applications were used for geottaged photos location on Google Maps, Google Earth or various social media sharing options during travel or in everyday life. The freely available Geomedia tools can redefine geographical locations such as Borgo Pass, Devil`s Plateau or God`s Chair, increasing their functionality and encouraging Dracula themed tourism development.

Although most people consider that Dracula phenomenon attracts international tourist almost everywhere in Romania, there is a significant preference for the historically rich geographical locations, such as Bran as Sighișoara which represent the functional Geosystem models. As we evaluated our data, we looked specifically at how efficient Geomedia techniques were in the construction and maintenance of semantic narratives surrounding Dracula phenomenon. Currently, Romania's internet availability and good quality connectivity establishes the tourism provider-consumers relationship. Airbnb phenomenon is opening the world for unique experiences, irrevocably changing today's tourism. A better search engine position on the first page increases any business performances, attracting more customers. The analysis finds that Airbnb search engine optimization locates any accommodation posting almost to the top of the Google search engine first page for free. The identification of specific historical geo-locations represented a challenge that has been solved with the help of old paper maps and different archive documents. The precise position determination and coordinates computation constituted the prerogatives of geospatial tools operations (Luo et al., 2009; Voda, 2018).

The study contributed to a better understanding of the Dracula phenomenon. A question that has generated a range of responses is why tourist visit Bran Castle, although Bram Stoker didn't mention it in his Dracula book and Vlad Tepes's presence there has never been historically validated. The answer is related to both social and geographical factors, proving Geomedia`s efficiency for the local Geosystem`s functionality increase. Bran Castle's interesting appearance corresponds well to the tourist expectation of their imagined image of Dracula's Castle. Although the spectacular Rasnov Fortress is located only $14 \mathrm{~km}$ from Bran Castle, most tourist prefer Bran because of the Dracula-Vlad Țepeș media association and mountain beautiful views. The Piatra Craiului Mountains jagged limestone crests from the East are shining in the sunrise, while Bucegi Massif conglomerate walls are reflecting the sunset light on sheer cliff faces. The Bran Castle tourist site was created in part with that imagery in mind, and Geomedia helps it attract more visitors each year, increasing the local Geosystem`s effectiveness.

Sighișoara's main tourist attraction is represented by the Vlad Dracul house, connected to Vlad Țepeș father, Vlad II, and promoted vigorously as "Dracula's" birth place. Positioned as it is in the old medieval citadel upon a hill, Vlad Dracul's house is surrounded by historical buildings, still inhabited as it was hundreds of years ago. Geomedia generated these historical links and the local Geosystem started to thrive.

The practical application of our findings may contribute to Borgo Pass, God`s Chair and Devil's Plateau Geosystems functionality increase through their strong connections to Bram Stoker's Dracula book (Stoker, 1897). Accurately described by the Irish writer, both geographical locations exist in the real world but lack in credible historical links to Vlad Țepeș. This is why fewer tourists visit these sites. It can be argued that visitors benefit from a variety of wild landscapes, local legends and traditional Romanian customs. These are the perfect prerequisites for sustainable tourism development, which involves local historical 
and natural environments, promoting community values and cultural conservation, increasing local welfare (UNWTO, 2013; Eadington \& Smith, 1992; Beeton, 2006; House, 1997; Picard, 2008; Weaver, 2006; Singh, 2012; Wang et al., 2019).

Dracula tourism growth is supposed to produce supplementary earnings for the community members, leading to the best administration of all Bistra Muresului and Piatra Fantanele resources (Lu \& Nepal, 2009; Voda \& Negru, 2017). Geomedia technology application should positively affect the local history and culture, enhancing people's geographical awareness and ancestor`s pride (Voda, Torpan \& Moldovan, 2017).

The analysis finds that in Romania, the myth of Dracula is unique and may become the most important functional attribute with the support of Geomedia tools (Voda \& Negru, 2015; Ernawati et al., 2018). Romanian tourism development benefits today of the Dracula fame, which attracts considerably more visitors in the region than any other traditional touristic brand. Dracula related spots identification problem arises when tourists try to decide what to visit before actually going there. The geographical place, mountain top or pass, medieval castle, ruins or any specific construction representations qualities are instantly affecting individual`s imagined experience of that place (Voda, 2013; Relph, 1976).

It is important to notice the Dracula phenomena geo-location confusions and Vlad T,epeș related places contradictions. The Geomedia tools were used to coordinate the conception of Dracula`s imagined experience through smartphone applications recent advancements and local geographical information systems assessment (Voda, 2013; Voda \& Negru, 2015). Transylvania is a Romanian historical province, located inside the Carpathian Mountains arch, where Bram Stoker, the Irish writer, placed the mysterious castle of Dracula. The world's most famous vampire was quite often associated and probably inspired by Vlad Țepeș, the tough Romanian ruler who used to impale his prisoners in times of war, bloodshed and persecution of political opponents (McNally \& Florescu, 1994; Voda \& Negru, 2017; Baca \& Rusu, 2017).

The results show the effectiveness of Geomedia techniques in Sighisoara and Bran geosystems` tourism development. From the individual household to the community scale, the Geomedia`s imagined place experience demonstrates the importance of geographical representations qualities in Borgo Pass, God`s Chair and Devil`s Plateau. Matter, energy and information input can balance a geosystem and increase its functionality. Matter can come in different forms of technological advancements and it is efficient if produces quantifiable outputs. For example, more accommodation facilities were created in Bran and Sighisoara due to Airbnb platform opportunities. Education increases any geosystem`s energy and has to be based on the historical and cultural traditions in order to contribute to a strong collective mind formation. Energy represents the connection with the local egregore as it is reflected in Bran and Sighisoara. Due to the internet technical evolution, information is widely available in Borgo Pass, God`s Chair and Devil's Plateau. But information without education is useless for the geosystem`s functionality.

\section{CONCLUSIONS}

This article examined the role of Geomedia techniques in developing Romania's Dracula themed tourism aided by a variety of freely available tools that local communities can use to present and promote their Geosystems`cultural and historical resources. Google Maps, Google Earth, Facebook and Airbnb constitute a robust Geomedia toolkit for the local community to use creatively. The analysis reveals that people's geographical space 
virtual signature will fundament the conception of the local Geomedia imagery built as an attraction site and a potential representation of a future tourist destination.

In addition to empirical research and practical implications, this study made a theoretical contribution and proposed the concept of a more secure form of development, based on education and access to information. Geomedia approach facilitates the inception and control of entire Geosystems where the contextual perception is validating the unique attributes and the digital revolution is empowering the place-based activities extension for the wellbeing of all inhabitants. If they have unity and responsible intelligence, people can easily define and regulate the energy, matter and information flows. Geosystem`s egregore preservation will fundament its adaptability to changes. People have to learn their living place history and actively maintain their ancient traditions for a strong collective mind formation.

This article contributes to the understanding why Geomedia controls Geosystems by synchronizing social etiquette, reshaping spatial imaginaries and harmonizing media interactions. The primary Vlad-Dracula geosystems brings numerous visitors to Bran Castle and the Vlad Dracul House in Sighișoara. International and local media promotion lends credibility in terms of genuine historical links to the Wallachian ruler, Vlad Țepeș. The rising number of Airbnb homes will soon surpass traditional tourist accommodations in Bran and Sighişoara, improving Geomedia's effectiveness and while providing extra income to locals.

Borgo Pass, Devil`s Plateau and God`s Chair are less known geographical locations. The accurate description in Bram Stoker`s book correlated with the real places stimulates 'les connaisseurs': Dracula Hunters. The more demanding access routes and the lack of local infrastucture is detering conventional tourists.

Geomedia`s smartphone applications are offering unique exploration insights of the world's most beautiful and intriguing geographical locations. From spectacular castles, forest trails, amazing waterfalls, winter wonderlands, astonishing mountain tops and underground caves, Google Earth`s smartphone application developed travel itineraries based on popular geo-tagged photos. Bram Stoker's Dracula is encouraging tourist to 'explore some of the places connected to Stoker`s Transylvanian vampire in Google Earth' (Google Earth, 2017).

Geomedia is generating unprecedented coverage of previously unknown places, opening new opportunities for researching the most mysterious Romanian geographical locations. Geomedia tools such as Google Pixel2 smartphone`s application Photo Sphere Camera, facilitates the elaboration of 360 images and their accurate geographical placement on Google Earth maps. Dracula based virtual reality might be created then for natural and cultural tourist resources valorization from Borgo Pass, God`s Chair and Devil`s Lake Scholomance geographical areas.

Based on the Romanian Dracula phenomenon, this research novelty resides in the unique attributes importance for each Geosystems` development and the future wider applicability of the Geomedia techniques for any Geosystem`s assessment.

We predict that more Dracula based experiences will develop the local Geosystems ' functionality and increase its effectiveness. Further geo-historical research should have a closer examination on the Dracula-Vlad Țepeș concealed interconnections.

The limitations of this research are strictly geographical since the Geomedia techniques can be applied in any world's region. Romania benefits from Dracula brand but the Geomedia approach is not restricted to well-known geographical locations. Geomedia is a means of developing Geosystems and the cultural values attached to them, creating an 
authentic experience of place, after digitally raising expectations that are hopefully met. In other words, Geomedia literally puts any remote Geosystem with all its cultural values and beliefs on the map.

Future research should have a closer examination on today's technological advances linkage with local communities' social responsibility. Everything is placed on a virtual map, emphasizing the importance of our presence, as humans, in the central part of our environment, the Geosystem. We have the power, as individuals, to create and control our own virtual reality, embedded in the geographical dynamic system. Bram Stoker's book related geographical locations will be widely spread by Geomedia tools, challenging the Romanian mountains wilderness exploration in search for Dracula's shadows.

\section{R E F E R E N C E S}

Airbnb (2018). Airbnb platform. [Online]. Available from:http://www.airbnb.com. [Accessed January 2018].

Anghel, C. (2006). Vlad Țepeș, înger și demon. Jurnalul National, [Online]. Available from: http://m.jurnalul.ro/vechiul-site/mitul-si-banii-25490.html. [Accessed October 2017].

Android Development (2016). Basic Android. [Online]. http://www.udacity.com. [Accessed January 2018].

ArcGIS Server, (2017). Website of ArcGIS Server. Environmental Systems Research Institute, [Online]. Available from: www.esri.com/software/arcgis/arcgisserver/.[Accessed December 2017].

Asero, V., Gozzo, Simona, and Venera Tomaselli (2016). Building Tourism Networks through Tourist Mobility, Journal of Travel Research, 55(6) 751-763.

Baca, I., Rusu, C. (2017). Borgo Pass: semnificatii geografice, istorice si culturale. Cluj Napoca: Argonaut.

Barbieri, C., Xu, S., Gil-Arroyo, C., and Rozier Rich, S. (2016). Agritourism, Farm Visit, or . . ? A Branding Assessment for Recreation on Farms, Journal of Travel Research, 55(8), 1094-1108.

Beeton, S. (2006). Community development through tourism. Collingwood, Australia: Landlinks Press.

Butulescu, V. (2001). Dracula- Carnavalul durerii. I.D. Bucharest: Sarbu Cultural Foundation Publishing House.

Cheng, M., \& Jin, X. (2019). What do Airbnb users care about? An analysis of online review comments, International Journal of Hospitality Management, 76 (A), 58-70.

Cherifi, B., Smith, A., Maitland, R., and Stevenson, N. (2014). Destination images of non-visitors. Annals of Tourism Research, 49, 190-202.

Croitoru, A., Crooks, A., Radzikowski, J., \& Stefanidis, A. (2013). Geosocial gauge: a system prototype for knowledge discovery from social media, International Journal of Geographical Information Science, 27:12, 2483-2508, DOI:10.1080/13658816.2013.825724.

Curta, F. (2014). Florin Curta on the real Dracula. [Online]. Available from: https://history.ufl.edu/2014/10/30/florin-curta-on-the-real-dracula/. [Accessed September 2015.

Dickinson, J.E., Ghali, K., Cherrett, T., Speed, C., Davies, N., Norgate, S. (2014). Tourism and the smartphone app: capabilities, emerging practice and scope in the travel domain. Current Issues in Tourism. 17(1), 84-101.

Echtner, C. M., \& Brent Ritchie, J. R. (2003). The meaning and measurement of destination image. The Journal of Tourism Studies, 14(1), 37-48.

Eadington, W. R., \& Smith, V. L. (1992). Introduction: The emergence of alternative form of tourism. In V. L. Smith and W. R. Eadington (Eds.), Tourism alternatives: Potential and problem in the development of tourism (pp.1-12). Phyladelphia, US: University of Pennsylvania Press.

Ernawati, N.M., Torpan, A., \& Voda, M. (2018). Geomedia role for mountain routes tourism development. Mesehe and Pisoiu Waterfall comparative study. Geographia Technica, 13 (1). 
Ernawati, N.M. (2015). Producer-market orientation of community-based tourism (CBT) products: A case study in Bali, Indonesia. Unpublished thesis. Perth: Edith Cowan University.

Ert, E., Fleischer, A., Magen, N. (2016). Trust and reputation in the sharing economy: The role of personal photos in Airbnb, Tourism Management, 55, 62-73.

Fairclough, N. (1995) Critical Discourse Analysis, Boston: Addison Wesley.

Gerard, E. (1885). Transylvanian Superstitions. The Nineteenth Century, v. 18, p. 128-144.

Giurescu, C.C., \& Giurescu, D.C. (1975). Istoria Românilor din cele mai vechi timpuri pînă astăzi (2nd edition). Bucureşti: Editura Albatros.

Google Earth (2017) Google Earth Smartphone App. [Online]. Available from: www.google.com/earth/. [Accessed December 2017].

Gunter, U. (2018). What makes an Airbnb host a superhost? Empirical evidence from San Francisco and the Bay Area. Tourism Management, 66, 26-37.

Gupta, S.K., Negru, R., \& Voda, M. (2018). The Indian Himalaya`s unique attributes: Hemkund Sahib and The Valley of Flowers. Geographia Technica, 13 (2), 62-73.

Guttentag, D. (2015). Airbnb: disruptive innovation and the rise of an informal tourism accommodation sector, Current Issues in Tourism, 18:12, 1192-1217.

Guttentag, D.A., \& Smith, S.L.J. (2017). Assessing Airbnb as a disruptive innovation relative to hotels: Substitution and comparative performance expectations, International Journal of Hospitality Management, 64, 1-10.

House, J. (1997). Redefining sustainability: A structural approach to sustainable tourism. In M. J. Stabler (Ed.), Tourism and sustainability principle to practice (pp. 89-104). Oxon, UK: Biddles ltd.

Hovi, T. (2014). The Use of History in Dracula Tourism, Folklore: Electronic Journal of Folklore, pp. 55-78, [Online]. Available from: http://www.folklore.ee/folklore/vol57/hovi.pdf. [Accessed November 2017].

Hwang, D., and Stewart, W.P. (2017). Social Capital and Collective Action in Rural Tourism. Journal of Travel Research, Vol. 56(1), 81-93.

Inal, C., Kocak, O., Esen, O., Bulbul, S. \& Kizgut, R. (2017). Surveying and Mapping using Mobile Phone in Archaeological Settlements. Geographia Technica, 12 (2), 82-96.

Jamal, T., Tanase, A. (2005). Impacts and Conflicts Surrounding Dracula Park, Romania: The Role of Sustainable Tourism Principles, Journal of Sustainable Tourism, 13:5, 440-445.

Jin, X., Gallagher, A., Cao L., Luo J. \& Han J. (2010) The wisdom of social multimedia: using Flickr for prediction and forecast. In Proceedings of ACM Multimedia.

Johnstone, B. (2002). Discourse analysis, Oxford: Blackwell Publishing.

Lai, K., \& Li, X.R. (2016). Tourism Destination Image: Conceptual Problems and Definitional Solutions, Journal of Travel Research, 55(8), 1065-1080.

Liang, S., Schuckert, M., Law, R., \& Chen, C. C. (2017). Be a "Superhost": The importance of badge systems for peer-to-peer rental accommodations. Tourism Management, 60, 454-465.

Lapenta, F. (2011). Geomedia: on location-based media, the changing status of collective image production and the emergence of social navigation systems, Visual Studies, 26:1, 14-24, DOI: 10.1080/1472586X.2011.548485.

Larson, M., Lundberg, C., \& Lexhagen, M. (2013). Thirsting for Vampire Tourism: Developing Pop Culture Destinations. Journal of Destination Marketing and Management, Vol. 2, No. 2, pp. 74 84.

Light, D. (2007). Dracula Tourism in Romania: Cultural Identity and the State, Annals of Tourism Research, 34, pp. 746-765.

Light, D. (2012). The Dracula Dilemma: Tourism, Identity and the State in Romania. Farnham: Ashgate.

Liu L., Wolfson O. \& Yin H. (2006) Extracting semantic location from outdoor positioning systems. In Proceedings of the IEEE International Conference on Mobile Data Management.

Luo Z, Li H, Tang J, Hong R, \& Chua T-S (2009) ViewFocus: explore places of interests on Google maps using photos with view direction filtering. In Proceedings of ACM Multimedia. 
Mac, I. (1996). Geomorfosfera și geomorfosistemele, Editura Presa Universitară Clujeană: Cluj Napoca.

Mânzat, I. (2008). Ecouri prin zig-zag-urile vietii. Bistrita: Mesagerul Publishing House.

McNally, T.R., \& Florescu, R. (1994). In search of Dracula: the History of Dracula and Vampires. New York: Houghton Mifflin Harcourt.

Meng, B., Min-Hyung, K. and Yeong-Hyeon, H. (2014). Users and Non-users of Smartphones for Travel: Differences in Factors Influencing the Adoption Decision, A.Pac.Jour.Tour.Res., DOI: 10.1080/10941665.2014.958508.

Miller, E. (2000). Dracula: Sense and Nonsense. Essex: Desert Island Books Limited.

Muresan, A., \& Smith, K.A. (1998). Dracula's castle in Transylvania: conflicting heritage marketing strategies. International Journal of Heritage Studies, 4(2), 86-102.

Negru, R., Voda, M. \& Dumitrache, N.D. (2015). Geodiversity assessment as a tool for Geotourism in the Istenszeke Natural Park. Academica Science Journal, Geographica Series, 1(6), 13-21.

Oișteanu, A. (2004). Ordine și haos. Mit și magie în cultura tradițională românească. București: Polirom.

Park, S., \& Carla Almeida Santos (2017) Exploring the Tourist Experience: A Sequential Approach, Journal of Travel Research, 56(1) 16-27.

Petru, C., \& Nastase, A. (2004). Tihuta- Hotelul lui Dracula de la Tihuta. [Online]. Available from: http://jurnalul.ro/campaniile-jurnalul/descoperirea-romaniei/12-iulie-2004-tihuta-hotelul-luidracula-de-la-tihuta-65193.html. [Accessed March 2015].

Picard, M. (2008). Balinese identity as tourist attraction from 'cultural tourism' (pariwisata budaya) to 'Bali erect' (ajeg Bali). Tourist Studies, 8(2), 155-173. doi: 10.1177/1468797608099246

Relph, E. (1976). Place and placelessness. London: Pion Limited, 156 p.

Reijnders, S. (2011). Stalking the Count: Dracula, Fandom and Tourism. Annals of Tourism Research, Vol. 38, No. 1, pp. 231-248.

Rinne, A. (2018), The dark side of the sharing economy. [Online]. Available from: https://www.weforum.org/agenda/2018/01/the-dark-side-of-the-sharing-economy/.[Accessed January 2018].

Roberts, L., \& Simpson, F. (1999), Developing Partnership Approaches to Tourism in Central and Eastern Europe, Journal of Sustainable Tourism, Volume 7, 3:4, 331-340.

Robinson, P. \& Wiltshier, P. (2011). Community tourism. In P. Robinson, S. Heitmann, and P. Dieke (Eds.), Research themes for tourism (pp. 87-99). Wallingford, UK: Cabi [Online]. Available from:

http://www.cabi.org.ezproxy.ecu.edu.au/CABeBooks/ShowPDF.aspx ?PAN=20113005506. [Accessed January 2018].

Schwanen, T. \& Kwan, M-P. (2008). The Internet, Mobile-phone and Space-time Constraints, Geoforum, 39 (3) 1362-1377.

Sidali, K. L., Huber, D., \& Schamel, G. (2017). Long-Term Sustainable Development of Tourism in South Tyrol: An Analysis of Tourists' Perception. Sustainability, 9(10), 1791.

Sigala, M. (2017). Collaborative commerce in tourism: Implications for research and industry. Current Issues in Tourism, 20, 346-355.

Singh, S. (2012). Community participation - in need of a fresh perspective. In T. V. Singh (Ed.), Aspects of tourism: Critical debates in tourism (pp. 113-117). Bristol, UK: Channel View Publications. 52.

Statista (2018). The statistics portal. [Online]. Available from: https://www.statista.com/statistics/smartphone-romania. [Accessed May 2018].

Stoker, B. (1897). Dracula, Westminister Archibald Constable and Company a Whitehall Gardens, London.

Stoicescu, N. (1976). Vlad Ţepeş. Bucureşti: Editura Academiei Republicii Socialiste România.

Torpan, A. \& Voda, M. (2019). Mountain Tracks Development Methodology for Adventure Recreation Activities in Gurghiu Mountains. Geographia Technica, 14 (1), 156-165.

Tussyadiah, I.P., Pesonen, J. (2016). Impacts of Peer-to-Peer Accommodation Use on Travel Patterns, Journal of Travel Research, 55(8) 1022-1040, DOI: 10.1177/0047287515608505. 
UNWTO (2016) United Nations World Tourism Organisation. Sustainable development of tourism. [Online]. Available from: http://sdt.unwto.org/en/content/about-us-5. [Accessed September 2016].

Valentino-DeVries, J. (2010). Using flickr photos as a travel guide. Wall Street J July 23. http://blogs.wsj.com/digits/2010/07/23/using-flickr-photos-as-a-travel-guide/.

[Accessed November 2016].

Voda, M., Kithiia, S., Jackiewicz, E., Du, Q., \& Sarpe C.A. (2019). Geosystems' Pathways to the Future of Sustainability. Scientific Reports. DOI: 10.1038/s41598-019-50937-z

Voda, M., \& Montes, Y.S. (2018). Descending mountain routes future: the North Yungas and Fagaras Geosystem`s comparative study. Geographia Technica, 13 (2), 152-166.

Voda, M., Negru, R. (2017). Dracula myth role in Isten Szek - Bistra Muresului tourism development. Volume of UDC 28-29.11.2017 International Conference 'Education Performance and Development', Risoprint Publishing House, Cluj Napoca, 166-171.

Voda, M., Torpan, A. \& Moldovan, L. (2017). Wild Carpathia Future Development: From Illegal Deforestation to ORV Sustainable Recreation. Sustainability, 9(2254), 1-11.

Voda, M. \& Negru, R. (2015). Geomedia role in Mures Valley Castles Tourism Development between Ogra and Brancovenesti. Academica Science Journal, Geographica Series, 1(6), 63-70.

Voda, M., Moldovan, L. Torpan, A. \& Henning, H. (2014). Using Gis for Mountain Wild Routes Assessment in Order to Qualify Them for Tourism Valorisation. Geographia Technica, 09 (1), 101-108.

Voda, M. (2013). The role of Geospatial Technologies, Geographic Information and ICT in promoting rural communities sustainable development in Transylvania. Academica Science Journal, Geographica Series, 3, 90-95.

Yanai, K., Yaegashi, K., Qiu, B. (2009). Detecting cultural differences using consumer-generated geotagged photos. In: Proceedings of the 2 nd international workshop on location and the web. ACM, New York, pp 1-4.

Zheng, Y-T., Zha, Z-J., Chua, T-S. (2010). Research and applications on georeferenced multimedia: a survey. Multimedia Tools Applications, 51, 77-98, DOI 10.1007/s11042-010-0630-z.

Wang, D., Park, S., \& Fesenmaier, D.R. (2012). The Role of Smartphones in Mediating the Tourism Experience. Journal of Travel Research, 51(4), 371-387.

Wang, D., Xiang, Z., \& Fesenmaier, D.R. (2016). Smartphone Use in Everyday Life and Travel, Journal of Travel Research, 55(1), 52-63.

Wang, D. \& Nicolau, J. L. (2017). Price determinants of sharing economy based accommodation rental: A study of listings from 33 cities on. International Journal of Hospitality Management, $62,120-131$.

Wang, K., Wang, M., Gan, C., \& Voda, M. (2019). Residents`Diachronic Perception of the Impacts of Ecological Resettlement in a World Heritage Site, International journal of environmental research and public health, 16 (19), 3556, https://doi.org/10.3390/ijerph16193556.

Weaver, D. (2006). Sustainable tourism theory and practice. Oxford, UK: Elsevier.

Wilson, M.W. (2012). Location-based services, conspicuous mobility, and the location-aware future. Geoforum 43, 1266-1275.

Wilson, M.W. (2014). Geospatial technologies in the location-aware future. Journal of Transport Geography, 34, 297-299.

Xiang, Z., Wang, D., \& O'Leary, J.T. (2015). Adapting to the Internet: Trends in Travelers' Use of the Web for Trip Planning, Journal of Travel Research, 54(4), 511-527. 